SAVANNAH RIVER LABORATORY

TECHNICAL DIVISION

\section{DISTRIBUTION}

G. F. CURTIN, WILM.

F. E. KRUESI

J. E. CONAWAY

J. T. GRANAGHAN, SRP

A. H. PETERS

T. HENDRICK

R. MAHER

C. B. GOODLETT

L. H. MEYER

H. J. CLARK

S. MIRSHAK, SRL

MEMORANDUM
J. R. HILLEY

J. L. CRANDALL

J. M. BOSWELL

J. A. KELLEY

S. D. HARRIS

R. M. WALLACE

M. I. HYDER

P. L. ROGGENKAMP

H. D. HARMON

J. F. ORTALDO

L. R. AUSTIN (3)

M. B. HUGHES (3)

DPST $-82-813$

A. S. JENNINGS

T. H. GOULD

R. W. BENJ AMIN

L. A. HEINRICH

J. E. HOISINGTON

D. E. HOSTETLER

I. M. MACAFEE

F. J. MCCROSSON

W. R. MCDONELL

G. F. O'NEILL

TIS FILES (2)

August 30, 1982

TO: P. L. ROGGENKAMP<smiles>C[As](C)=[W]=[V]</smiles>

FROM: J. E. HOISINGTON/W. R. MCDONELL

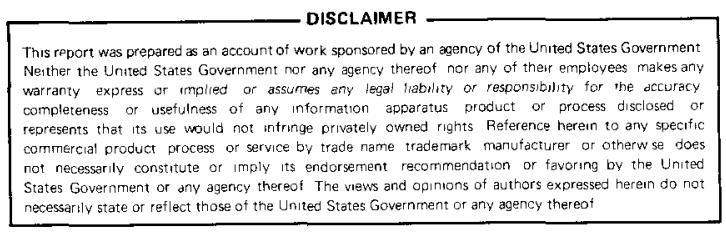

\title{
STRONTIUM-90 AND PROMETHIUM-147 RECOVERY
}

\section{INTRODUCTION}

Strontium-90 and promethium-147 are fission product radionuclides with potential for use as heat source materials in high reliability, non-interruptible power supplies. Interest has recently been expressed in their utilization for Department of Defense (DOD) applications. This memorandum summarizes the current inventories, the annual production rates, and the posible recovery of $\mathrm{Sr}-90$ and $\mathrm{Pm}-147$ from nuclear materials production operations at Hanford and Savannah River. Recovery of these isotopes from LWR spent fuel utilizing the Barnwell Nuclear Fuels Plant (BNFP) is also considered. Unit recovery costs at each site are provided.

\section{$\underline{\text { SUMMARY }}$}

Potential DOD requirements for $\mathrm{Sr}-90$ or equivalent heat source radionuclides could total $150 \mathrm{MCi}$ ( $1 \mathrm{MW}$ thermal) by FY1990. It would be necessary to undertake $\mathrm{Sr}-90$ recovery operations at SRP, Hanford and BNFP to meet these DOD FY1990 delivery requirements. Although the high level waste (HLW) inventories at SRP and Hanford contain $120 \mathrm{MCi}$ of $\mathrm{Sr}-90$ each, their Sr-90 is unacceptable for DOD use because the isotopic purity is less than $40 \%$ due to radioactive decay of the $\mathrm{Sr}-90$ and dilution with natural strontium 


\section{DISCLAIMER}

This report was prepared as an account of work sponsored by an agency of the United States Government. Neither the United States Government nor any agency Thereof, nor any of their employees, makes any warranty, express or implied, or assumes any legal liability or responsibility for the accuracy, completeness, or usefulness of any information, apparatus, product, or process disclosed, or represents that its use would not infringe privately owned rights. Reference herein to any specific commercial product, process, or service by trade name, trademark, manufacturer, or otherwise does not necessarily constitute or imply its endorsement, recommendation, or favoring by the United States Government or any agency thereof. The views and opinions of authors expressed herein do not necessarily state or reflect those of the United States Government or any agency thereof. 


\section{DISCLAIMER}

Portions of this document may be illegible in electronic image products. Images are produced from the best available original document. 
present in the caustic used for waste neutralization. To meet the DOD requirements $5 r-90$ must be recovered from fresh acid wastes. Hanford would need to recover an average of $2.3 \mathrm{MCi} /$ year from fresh, acid Purex waste beginning in FY1985. SRP and BNFP recovery operations must start in FY1988. The SRP recovery rate is about $7.2 \mathrm{MCi} /$ year from fresh waste. The BNFP recovery rate is 25 to $45 \mathrm{MCi}$ year depending on the age and burnup of the LWR spent fuel processed.

SRP and Hanford alone can meet the FY1990 DOD demand without reprocessing LWR spent fuel if the isotopic purity requirements are lowered to $30 \%$ or greater Sr-90. SRP can supply approximately 50 $\mathrm{MCi}$ and Hanford can supply approximately $100 \mathrm{MCi}$ of $\mathrm{Sr}-90$ by blending the low purity $\mathrm{Sr}-90$ in the HLW inventories with the higher purity $\mathrm{Sr}-90$ recovered from fresh wastes.

About $45 \mathrm{MCi}$ per year of $\mathrm{Pm}-147$ can be recovered from fresh wastes at SRP and Hanford in conjunction with $\mathrm{Sr}-90$ recovery. The short 2.6 year half-life of $\mathrm{Pm}-147$ makes recovery from the existing HLW inventories unattractive. An additional $14 \mathrm{MCi} / \mathrm{yr}$ could be obtained if BNFP were to process 5-year old LWR spent fuel.

The Sr-90 unit recovery costs at SRP and BNFP are based on capital and operating cost estimates for the lead carrier sulfate precipitation process. The $\mathrm{Sr}-90$ unit recovery costs are $\$ 1.15 / \mathrm{Ci}$ from SRP fresh acid wastes, $\$ 2.73 / \mathrm{Ci}$ from Defense Waste Processing Facility (DWPF) waste sludges, and $\$ 0.88 / \mathrm{Ci}$ or $\$ 1.59 / \mathrm{Ci}$ from BNFP processing 5-year old or 20-year old LWR spent fuel, respectively. These unit costs, expressed in FY1983 dollars, are based on a discounted cash flow analysis over a 15 year study period. Capital and operating costs for Sr-90 recovery at Hanford are not available. Because portions of the required facilities are in place at Hanford, unit recovery costs there are expected to be less than those at SRP or BNFP.

Promethium-147 unit recovery costs are estimated to be $\$ 0.15 / \mathrm{Ci}$ from SRP fresh waste and $\$ 1.72 / \mathrm{Ci}$ from processing 5-year old LWR spent fuel at BNFP. Costs at Hanford are expected to be similar to the SRP costs since Hanford currently does not recover $P m-147$.

\section{DISCUSSION}

\section{Projected Requirements}

Although no firm projections of DOD requirements for heat source radionuclides are available, informal discussions with DOEHeadquarters and Hanford personnel indicate that prospective applications could require a total heat output of 1 MW or more to 
power a series of thermoelectric generator units with $2 \mathrm{~kW}$ electrical outputs. In addition, many smaller units up to $500 \mathrm{~W}$ (electric) might also be required. Emplacement of the units by FY1990 is indicated.

Strontium-90 and promethium-147 are potential heat source materials for high reliability, non-interruptable power supplies. 1 Strontium-90 ( $148 \mathrm{Ci} /$ watt, half-life 28 years) has been used to power automatic weather, navigation, and communication stations in both terrestrial and marine environments. 1,2 Promethium-147 ( $2788 \mathrm{Ci} /$ watt, half-life 2.6 years) has been developed for use as a thermal power source in specialized instrumentation systems. 1,3

The DOD Sr-90 applications would employ a general purpose heat source developed by Teledyne. The heat source utilizes SrF2 doubly encapulated in metal containers. 4 Capsule designs are shown in Figure 1. Strontium fluoride compacts of about 2-in. diameter are contained in an inner capsule of Hastelloy C-276 with wall thickness about 0.13 in., and an outer capsule of Hastelloy $\mathrm{C}-4$ or $\mathrm{S}$ with about $0.50-i n$. wall thickness. Both capsules are sealed by welded end plugs. Outside dimensions of the outer capsule including end plugs are 3.37-in. in diameter and about 20-in. in length. The heat load of the capsule is about 1000 watts ( 148 $\mathrm{Ci} /$ watt). With a $\mathrm{Sr}-90$ isotopic purity of $55 \%$ the capsule power density is 1 watt/cc. The heat source design requires a minimum Sr-90 purity of $40 \%$ to maintain the thermal power density required for thermoelectric generators.

No heat source design for the Pm-147 applications has been specified, but previous development indicates this radionuclide would be used as $\mathrm{Pm}_{2} \mathrm{O}_{3}$ pellets in heater units or thermoelectric generators similar to the Sr-90 units. 3

\section{Existing Inventories}

\section{Strontium-90}

Strontium-90 in existing high level waste (HLW) inventories at SRP and Hanford and in LWR spent fuel total approximately $540 \mathrm{MCi}$. Table 1 shows the amount and the isotopic content of each inventory. The SRP and the Hanford HLW each contain approximately 120 $\mathrm{MCi}$ of strontium-90.5,6 The LWR spent fuels contain $300 \mathrm{MCi} .5$

The strontium-90 in the SRP HLW is concentrated almost entirely in the sludge. While the amount of strontium-90 is reasonably well known ( $120 \mathrm{MCi})$, the exact isotopic purity remains to be determined. As formed during U-235 fission, the Sr-90 isotopic fraction is about 0.6 with most of the remaining strontium being nonradioactive Sr-88. Dilution of the $\mathrm{Sr}-90$ isotopic fraction in 
DP ST $-82-813$

August 30,1982

stored waste inventories results from the decay of $\mathrm{Sr}-90$ relative to the non-radioactive strontium and from the addition of nonradioactive strontium as impurties in the chemicals (especially $\mathrm{NaOH}$ ) during the separations process. Historically, the amount of naturally occurring $S r$ in the SRP caustic has ranged from 2 to 18 ppm. 7 As of 1965, it was estimated that half the Sr-90 in SRP waste had an isotopic purity of $50 \%$ or greater and half had an isotopic purity of $20-49 \% .7$ Since 1965 , an additional 17 years of waste has been neutralized with caustic of undetermined purity and waste management programs have mixed the sludge of several waste tanks. The isotopic purity of the current inventory is estimated to be an average of $35 \% \mathrm{Sr}-90$. The Analytical Chemistry Division is analyzing several HLW samples to determine the isotopic purity of SRP Sr-90.

The Hanford strontium-90 inventory of $120 \mathrm{MCi}$ exists in two forms. Approximately $50 \mathrm{MCi}$ has been removed from the HLW and is stored in capsules as $\mathrm{SrF}_{2} .5$ The remaining $70 \mathrm{MCi}$ exists unrecovered in the HLW. Most of the Hanford Sr-90 has been diluted with stable natural $\mathrm{Sr}$ in the caustic used for neutralization, resulting in an isotopic purity that ranges from 20 to $40 \%$. About $10 \mathrm{MCi}$ of the encapsulated $\mathrm{Sr}$ has an isotopic purity greater than $40 \%$; this product was recovered from the acid Purex waste stream before neutralization during the last production campaign which ended in 1972.

Hanford also has about $12 \mathrm{MCi}$ of undiluted $\mathrm{Sr}-90$ in $\mathrm{N}$-reactor fuel (2800 MTU) irradiated between 1972 and 1981. This fuel is in cooling basins awaiting the scheduled FY1984 restart of the Purex processing plant.

The Sr-90 inventory in LWR spent fuel is estimated at $300 \mathrm{MCi}$. This inventory is distributed throughout the country in the cooling basins of power reactors. Since the fuel has not been processed, the only dilution in isotopic purity is that due to radioactive decay.

\section{Promethium-147}

Existing high-level wastes contain promethium-147 in relatively small quantities, about $85 \mathrm{MCi}$ at Savannah River and $14 \mathrm{MCi}$ at Hanford. 5,6 The inventory of unprocessed LWR spent fuel contains an additional estimated $400 \mathrm{MCi}$ of Pm-147 (Table 2).5

Annual Production

\section{Strontium-90}

The annual reactor production of $\mathrm{Sr}-90$ is shown in Table 1 . LWR power reactors produce by far the most $\mathrm{Sr}-90$, about $71 \mathrm{MCi} / \mathrm{yr}$ in the U.S. 5 Four SRP reactors produce about $10.0 \mathrm{MCi} / \mathrm{yr} .6,7,8$ The 
DP ST $-82-813$

August 30,1982

Hanford $\mathrm{N}$-reactor should produce only about $25 \%$ as much as SRP or $2.5 \mathrm{MCi} / \mathrm{yr}$. The proposed SRP $\mathrm{Sr}-90$ recovery process is assumed to be $72 \%$ efficient recovering $7.2 \mathrm{MCi} /$ year of $\mathrm{Sr}-90$ from fresh acid waste. The Hanford $\mathrm{Sr}-90$ process is approximately $90 \%$ efficient, recovering $2.3 \mathrm{MCi}$ /year from fresh Purex waste. BNFP could recover $45 \mathrm{MCi} /$ year of $\mathrm{Sr}-90$ from 5-year old LWR spent fuel and 25 $\mathrm{MCi} /$ year from 20-year old fuel when processing $1500 \mathrm{MTU} /$ year with a $72 \%$ efficient $\mathrm{Sr}-90$ recovery process.

\section{Promethium-147}

Annual reactor production of $\mathrm{Pm}-147$ is estimated to be about 50 $\mathrm{MCi}$ at. Savannah River, $12 \mathrm{MCi}$ at Hanford, and $135 \mathrm{MCi}$ from commercial LWR operation ( $T a b l e ~ 2)$. Annual production is a major fraction of existing inventory because of the short half-life of $\mathrm{Pm}-147$. The quantities of $\mathrm{Pm}-147$ potentially available from SRP and Hanford for heat source applications are $36.0 \mathrm{MCi} / \mathrm{yr}$ and 11 $\mathrm{MCi} / \mathrm{yr}$, respectively. These values are based on the recovery efficiencies assumed for $S r-90$. The recovery of $\mathrm{Pm}-147$ from LWR spent fuel is only attractive when reprocessing relatively fresh spent fuel. Approximately $14 \mathrm{MCi} / \mathrm{yr}$ can be recovered at $\mathrm{BNF} P$ when processing 5-year old fuel. Recovery from 20-year old fuel would produce less than $0.1 \mathrm{MCi} / \mathrm{yr}$.

\section{Recovery Processes}

\section{Strontium-90}

Strontium-90 in the SRP acid waste stream would be recovered using a lead-carrier sulfate precipitation process. 9 The precipitation process was chosen over the solvent extraction method currently used by Hanford because of space limitations in the SRP canyons. 2 The proposed precipitation process is shown in Figure 2. Strontium is precipitated from the high activity waste concentrate (HAWC) stream at an acidity high enough (usually 2 to $4 \mathrm{M} \mathrm{HNO}_{3}$ ) that the rare earth elements remain in solution. 10 The solution is centrifuged, with the centrate (containing the remaining fission products) sent to neutralization. The solid precipitates, mostly $\mathrm{Pb}$ and $\mathrm{Sr}$ sulfates, are metathesized with sodium carbonate to convert the sulfates to carbonates. This solution is centrifuged with the centrate also sent to neutralization. The $\mathrm{Pb}-\mathrm{Sr}$ carbonates are then dissolved in nitric acid to produce a nitrate solution suitable for conversion to $\mathrm{SrF}_{2}$ and encapsulation. The literature indicates an $80 \%$ recovery of $\mathrm{Sr}-90$ from the HAWC stream can be expected. 10

a. With an R\&D program it is possible that an ion exchange process could be developed that would offer less processing difficulty and better yields. Ion exchange costs are expected to be somewhat lower than for the precipitation process. 
Strontium-90 recovery from the existing Savannah River HI' sludge can be conducted using the same precipitation process. Figure 3 shows a potential flowsheet for Sr-90 recovery from the existing HLW inventory. Before $\mathrm{Sr}$ can be recovered, the sludge feed is dissolved in nitric acid. The $\mathrm{Sr}$ is then precipitated with lead sulfate, metathesized, and converted to nitrate. The residual solution is denitrated with formic acid for $\mathrm{Hg}$ removal and to provide the proper feed characteristics for vitrification in the DWPF. The denitrater offgas is passed over hydrogen mordenite to decompose $\mathrm{NO}_{\mathrm{x}}$, producing a $\mathrm{N}_{2}$ and $\mathrm{CO}_{2}$ offgas stream that can be vented to the atmosphere. Il

Hanford routinely removes cesium-137 and strontium-90 from neutralized HLW. Aged alkaline waste is dissolved with nitric acid in the B-plant fractionization process. Strontium is recovered and purified by processing the dissolved sludge through the B-plant solvent extraction system. The purified Sr nitrate solution is then transferred to the Waste Encapsulation and Storage Facility (WESF) where it is converted to $\mathrm{SrF}_{2}$, which is encapsulated for long term storage or future use. 12

Hanford also has the capability in B-plant to recover both Cs-137 and $5 r-90$ from the fresh Purex waste stream before neutralization. The Cs-137 is removed from the acid waste stream with ionexchange. The $\mathrm{Sr}$ is partitioned and purified from the remaining fission products using solvent extraction. The $\mathrm{Sr}$ nitrate product is sent to WESF for conversion to $\mathrm{SrF}_{2}$ and encapsulation. 12

Sr-90 recovery from LWR spent fuel at BNFP can be accomplished by utilizing the lead carrier sulfate precipitation process outlined for $\mathrm{Sr}-90$ separation from SRP acid wastes. The $\mathrm{Sr}$ is precipitated from the high acid fission product stream with lead sulfate. The precipitates are centrifuged, metathesized, and acidified before conversion to $\mathrm{SrF}_{2}$ and encapsulation. Since BNFP utilizes stainless steel waste tanks, the centrate acid waste does not require neutralization.

\section{Promethium-147}

The recovery of $\mathrm{Pm}-147$ in conjunction with Sr-90 from the SRP acid waste stream can also be accomplished using the lead sulfate carrier precipitation process. The process flowsheet is shown in Figure 4. The flowsheet assumes $80 \%$ recovery of both $\mathrm{Sr}$ and $\mathrm{Pm}$ from the fission product stream. In order to precipitate Pm, the acid concentration of the fission product stream must be reduced from $2 \mathrm{M} \mathrm{HNO}_{3}$ to $0.01 \mathrm{M}$. This is done by partially neutralizing the fission product stream before conducting the sulfate precipitation. Strontium and the rare earth elements, including Pm-147, will then precipitate. ${ }^{9}$ The precipitates are centrifuged, metathesized, and acidified for purification and encapsulation. 
DPST $-82-813$

August $30,198 ?$

Recovery of Pm-147 from the existing Savannah River HLW inventory does not appear worthwhile because of the small quantities of the short-lived radionuclide present. At the time of recovery, the average age of the SRP inventory will be about 20 years (eight Pm-147 half lives). The recovery of Pm-147 from SRP HLW is not considered in this evaluation.

Hanford could recover Pm-147 from the fresh acid waste stream produced during Purex processing. The B-plant solvent extraction system would be modified to partition Sr-90 from the rare earth elements.

The small amount of Pm in the existing Hanford wastes makes Pm-147 recovery unattractive.

The process for Pm-147 recovery from LWR spent fuel is similar to that described for SRP acid wastes. The acid concentration of the fission product stream is reduced to precipitate both strontium and promethium. The precipitates are centrifuged, metathesized and acidified to prepare a nitrate solution suitable for radionuclide purification and encapsulation.

\section{Encapsulation Process}

\section{Strontium-90}

The Sr-90 heat source capsules can be produced using the same $\mathrm{SrF}_{2}$ conversion and encapsulation process at SRP, Hanford, and BNFP. The proposed process is identical to current Hanford encapsulation process with the addition of a hot pressing operation. (Hot pressing is required to obtain the power density required for the general purpose heat source.) Hanford experience indicates that encapsulation process yields of $90 \%$ can be obtained. This, combined with the separations yield of $80 \%$, gives an overall $\mathrm{Sr}-90$ recovery efficiency of $72 \%$.

A representative flowsheet for processing of recovered $\mathrm{Sr}-90$ into heat source capsules is shown in Figure 5. The strontium feed, received in a nitrate solution, is purified by ion exchange to separate the strontium fraction from the lead carrier and other impurities in the solution. After adjustment to a basic solution, strontium fluoride is precipitated by addition of sodium fluoride powder. The precipitate is filtered and washed using sintered metal filters. After air-drying, the filter cake is transferred to furnace boats and heated to $1100^{\circ} \mathrm{C}$. The dried filter cake is crushed into particles appropriate for forming into pellets by hot pressing techniques. (Pre-pressing at low temperature followed by crushing and screening of the cold pressed compact may be necessary to obtain the particle sizes required for hot pressing.) The powders are hot pressed at $900-1000^{\circ} \mathrm{C}$ under inert atmosphere to form cylindrical pellets of about $90 \%$ theoretical density. 
After gaging, the hot-pressed pellets are assembled into the inner and outer capsules which form the heat source. The inner capsules, after closure with circumferentially welded end caps, are weld-inspected, helium leak-tested, and cleaned to a non-smearable contamination level, before insertion into the outer capsule. The outer capsules are closed by circumferentially welded end-caps of a special interlocking design. Following weld inspection, helium-leak-testing, and final decontamination, the $\mathrm{Sr}-90$ heat source capsules are stored under water pending offsite shipment.

\section{Promethium-147}

Modifications of the $\mathrm{Sr}-90$ encapsulation flowsheet to accommodate concurrent Pm-147 encapsulation are included in Figure 5. The as-received feed contains rare earth nuclides, including $\mathrm{Pm}-147$ as well as Sr-90. The rare earths are separated from the strontium by ion exchange. The promethium is recovered chromatographically from the rare earths in nitric acid solution. The promethium is then precipitated as an oxalate, filtered, dried, and calcined to promethium oxide $\left(\mathrm{Pm}_{2} \mathrm{O}_{3}\right)$. The oxide is formed into pellets by hot pressing of screened particles produced by breakup of a cold-pressed compact. $\mathrm{Pm}_{2} \mathrm{O}_{3}$ particles are hot pressed at $1500^{\circ} \mathrm{C}$ in an inert atmosphere to produce pellets greater than $90 \%$ theoretical density. The heat source is assembled by loading the $\mathrm{Pm}_{2} \mathrm{O}_{3}$ pellets into the inner and then the outer capsules of appropriate heat-resistant alloys using procedures analogous to those for $\mathrm{Sr}-90$ capsules.

\section{Facilities Required}

\section{Strontium-90}

To provide Sr-90 recovery capability from SRP acid waste both canyons require modification. The canyons must be provided with an additional centrifuge and several processing tanks for the precipitation, metathesis, and acidification operations. In F-canyon, space for Sr-90 processing equipment could be made available by removing the $1 \mathrm{~A}$ bank jumbo mixer-settlers (not currently used) and by reallocating the existing canyon tankage. Space in H-canyon could be made available by removing one or two non-essential tanks and by reallocating the remaining tanks. An alternative would be to remove the H-frames and install the $\mathrm{Sr}-90$ equipment in their place. This alternative requires no HM process modifications, but eliminates the site $\mathrm{Pu}-238$ production capability.

All strontium nitrate solutions recovered in H-canyon would be transported to F-canyon for purification and encapsulation in the Multi-Purpose Processing Facility (MPPF). In addition to the Sr-90 recovery equipment, H-canyon would need Sr-nitrate loadout facilities and $\mathrm{F}$-canyon would need $\mathrm{Sr}$-nitrate receiving facilities. 
DPST $-82-813$

August 30,1982

The recovery of Sr-90 from the existing HLW inventory requires an increase of $15 \%$ in the size of the DWPF main processing building. This is based on an estimate of space requirements needed for Sr-90 recovery recently completed by the DWPF liaison group. 13 The precipitation, centrifugation, metathesis, and the formic acid denitration steps are conducted in the main processing building. The recovered $\mathrm{Sr}$ nitrate solution is shipped to MPPF for conversion to $\mathrm{SrF}_{2}$ and encapsulation.

The Multi-Purpose Processing Facility (MPPF) would be used to encapsulate the Sr-90 recovered at SRP. The MPPF, with the layout shown in Figure 6 , is a concrete-shielded ( $5.5 \mathrm{ft}$ thick) facility equipped with viewing windows and masterslave manipulators. 14 The facility was designed for separation and purification of large quantities of transplutonium elements (Am-241, Cm-244, Cf-252) using chromatographic ion-exchange techniques. Process and service equipment, mounted on replaceable racks, is operated from eight viewing stations. Currently installed equipment provides capability for chromatographic ion exchange, precipitation, calcination, packaging, finishing, storage, and analytical control operations.

Almost all the equipment currently installed in the MPPF is expected to require extensive modification or replacement for Sr-90 encapsulation. The existing equipment does not appear to have the required throughput capability required for a $\mathrm{Sr}-90$ encapsulation program. However, a detailed engineering review of the facility capabilities should be conducted to verify the current facility capacity. The MPPF would also require hot- and cold-pressing capability.

Hot pressing capability is assumed for purposes of this evaluation to be provided by a resistance heated press suitable for manipulator operation in the MPPF. The hot press would be capable of 5000 psi loads at temperatures up to $1500^{\circ} \mathrm{C}$, using either graphite or metal dies in inert or reducing atmospheres. Two such hot presses were recently procured for but not installed in the SRL High Level Caves. Induction heated presses operated at high temperature in vacuum atmosphere, as currently employed for glove box processing of $238 \mathrm{PuO}_{2}$ fue 1 forms, appear too bulky for MPPF installation.

Hanford currently removes Cs-137 and Sr-90 from the HLW with the B-plant fractionization process. Contacts with Pacific Northwest Laboratories (PNL) personnel indicate the B-plant process could easily be converted to process fresh acid waste from Purex. A new waste header from Purex to B-plant and some minor modifications to the $C s$ removal colums would be required. 
Process equipment for Sr-90 encapsulation at Hanford is located in the Waste Encapsulation and Storage Facility (WESF). 15 This Eacility is operated in conjunction with the B-Plant for recovery of $\mathrm{Sr}-90$ and $\mathrm{Cs}-137$. The WESF is a shielded, manipulator-operated facility similar in basic configuration to the Savannah River MPPF. Strontium-90 is currently encapsulated as SrF 2 using a process analogous to that already described except that the $\mathrm{SrF}_{2}$ is compacted within the inner capsule by pneumatic impaction, in a cold-pressing operation achieving 65-70\% theoretical density. The inner capsules are sealed into Type $316 \mathrm{~L}$ stainless steel outer capsules designed only for underwater storage. For heat source uses, the outer stainless steel capsules of the WESF storage design must be replaced by the thick walled Hastelloy $\mathrm{C}-4$ or $\mathrm{S}$ outer capsules previously specified. 4

The WESF would require hot-pressing capability before heat source quality $\mathrm{SrF}_{2}$ capsules could be produced. Installation of this capability in the existing facility should be straightforward requiring only minor modifications.' All other equipment currently in use in the B-plant and WESF is suitable for production of Sr-90 heat source capsules.

Separation and encapsulation of $5 r-90$ recovered at BNFP from LWR spent fuel would require installation of special facilities. BNFP, as built, has the capability of separating uranium and plutonium from the acid fission product stream. Uranium is converted to $\mathrm{UF}_{6}$ and plutonium is stored as a nitrate solution. 16 The precipitation tanks and centrifugation equipment required to separate the Sr-90 from the other fission products would be located in shielded areas near the existing solvent extraction equipment. Remote cells similar to the SRP MPPF would be required to purify and encapsulate the Sr-90. BNFP must construct similar type facilities for converting $\mathrm{Pu}$ nitrate to $\mathrm{PuO}_{2}$ before it could begin reprocessing spent fuel. The cost of the $\mathrm{Sr}$ encapsulation facilities could be minimized by combining them with the Pu conversion facility.

\section{Promethium-147}

Most of the facilities required for SRP Sr-90 recovery are suitable for Pm-147 recovery. The precipitation equipment required in the SRP canyons for Sr-90 can be used without modification for concurrent $\mathrm{Sr}-90 / \mathrm{Pm}-147$ recovery. The MPPF as modified for $\mathrm{Sr}-90$ encapsulation can also be used for $\mathrm{Pm}-147$. The basic equipment required is similar for both radionuclides. Some minor modifications may be required to provide the MPPF with the capability of encapsulating two products. 
Pm-147 recovery at. Hanford and BNFP would also employ the same facilities provided for Sr-90. Minor modifications in the encapsulation facilities would be required to support the additional product output.

\section{Costs and Schedules}

\section{Strontium-90}

The total capital cost for removing Sr-90 from fresh SRP waste is estimated at 30 million FY1983 dollars. No R\&D costs are included. $F$ and $H$ canyons would require approximately $\$ 10$ million each for the Sr-90 recovery modifications. These estimates are based on canyon equipment replacement costs, 17 escalated to total a project cost based on recent Engineering Department estimates. 18 The required modifications to the MPPF facilities are estimated at 10 million dollars. This is based on replacing each of the existing eight equipment racks at $\$ 1$ million each with an additional $\$ 2$ million allowance for interim capsule storage and load-out facilities. The MPPF costs could be significantly lower if some of the currently installed equipment is utilized.

Operating costs are estimated at $\$ 3 \mathrm{million} /$ year. 19 Most of the annual SRP operating expenses would be incurred in MPPF for Sr-90 purification and encapsulation. The incremental $F$ and $H$ canyon operating costs for Sr-90 recovery should be minimal. Operation of the additional equipment in the "hot" canyons should not require any additional manpower and only minimal increases in cold chemical feeds.

Initial Sr-90 recovery from fresh SRP waste could begin in FY1988. This assumes a FY1986 project with all design completed in FY1986. Construction of the required facilities would be completed in FY1987 with startup in FY1988. Supplemental funding could advance the startup two years to FY1986.

The capital costs for the recovery of $\mathrm{Sr}-90$ from acidified HLW sludge in the DWPF and encapsulation in MPPF is estimated at 100 million FY1983 dollars. The capital cost is based on recent Engineering Department estimates of DWPF construction costs 20 and an estimate of space requirements needed for $\mathrm{Sr}-90$ recovery conducted by the DWPF liaison group. 13 The $\$ 100$ million cost reflects a $15 \%$ increase in the size of the DWPF main processing building. The DWPF liaison group estimated a $50 \%$ increase in the processing building size to accommodate both separation and encapsulation operations using the Hanford solvent extraction flowsheet. The selection of the less space intensive precipitation process and encapsulation in MPPF reduced the liaison group 
estimate by a factor of three to a $15 \%$ size increase. As before, no R\&D costs are included.

The incremental DWPF operating cost for $\mathrm{Sr}-90$ removal is estimated at $\$ 5$ million/year. This is $15 \%$ of the annua 1 DWPF operating cost published in Reference 21.

If both separation and encapsulation operations are conducted in the DWPF, the capital costs double to $\$ 200$ million. The space requirements would be about two-thirds of those estimated by the DWPF liaison group for $\mathrm{Sr}-90$ recovery using the Hanford flowsheet. Use of high cost DWPF space in place of the MPPF facilities for product encapsulation operations would considerably increase Sr-90 recovery costs, but could become necessary if the MPPF facilities were required for other uses. Incremental operating costs would double to $\$ 10 \mathrm{million} / \mathrm{yr}$.

Initial recovery of Sr-90 from the existing SRP waste inventory would begin in FY1988, about the time of the projected DWPF startup.

Capital and operating costs for recovery of $\mathrm{Sr}-90$ at Hanford are not available. Contacts with $\mathrm{PNL}$ personnel indicate that the Sr recovery costs from fresh acid Purex waste should be comparable to SRP fresh acid waste recovery costs. The costs for Sr recovery from the existing waste inventory at Hanford are expected to be significantly lower than the estimated SRP recovery cost. The B-plant and WESF facilities have been operational for ten years and will require little or no modifications to complete $\mathrm{Sr}$ removal from the existing inventory. Installation of hot pressing capability in WESF would be required to encapsulate Sr-90 into high density heat source forms.

The Hanford WESF could supply Sr capsules as soon as hot pressing capability is available providing the isotopic purity of the existing inventory is satisfactory. Recovery of Sr-90 from fresh acid waste would not begin until FY1985. A year delay from the FY1984 Purex startup is assumed to provide a working inventory for B-plant.

The cost of $\mathrm{Sr}$ removal facilites at BNFP is estimated at 100 mil1ion FY1983 dollars. 9 This is $50 \%$ of the capital cost estimate reported by Exxon in 1977 , for a cesium and strontium recovery facility escalated to FY1983 dollars. 9 About $50 \%$ of the capital would be required for the separations facilities and $50 \%$ for the encapsulation facilities. The annual operating cost is estimated at $\$ 20$ million. As with the capital cost, the operating cost is $50 \%$ of that reported for the Exxon plant, 9 escalated to FY1983 dollars. No R\&D costs are included. 
Strontium-90 cannot be recovered at BNFP until the facility begins reprocessing LWR spent fuel. Projected startup in FY1988 would require immediate funding authorization for spent-fuel reprocessing.

\section{Promethium -147}

The total capital cost for recovering $\mathrm{Sr}$ and $\mathrm{Pm}$ from fresh SRP waste is estimated at 35 million 1983 dollars. This is an incremental increase of $\$ 5$ million over the corresponding Sr-90 only recovery costs, to cover additional equipment required in the MPPF to process the two products concurrently. No additional canyon facilities are required for Pm- 147 recovery beyond those needed for $\mathrm{Sr}-90$ recovery. The MPPF operating costs for $\mathrm{Pm}-147$ and $\mathrm{Sr}-90$ recovery are estimated to increase by $50 \%$ to $\$ 4.5 \mathrm{million} /$ year over those for Sr-90 alone. No additional operational costs are expected in the canyon for recovery of $\mathrm{Pm}$. As for $\mathrm{Sr}$, no $\mathrm{R} \& \mathrm{D}$ costs are included. Recovery of Pm would begin in FY1988 at the same time as $\mathrm{Sr}-90$ recovery.

The capital and operating costs for recovery of Pm-147 at Hanford are not available. It is expected that the amounts of capital required to provide $\mathrm{Pm}$ encapsulation capability in the WESF would be about equal to that for the MPPF. The WESF operating costs are expected to increase about $50 \%$ as was the case with MPPF. B-plant would probably require no significant modifications for recovery of $\mathrm{Pm}-147$ in addition to $\mathrm{Sr}-90$.

The recovery of $\mathrm{Pm}-147$ in conjunction with $\mathrm{Sr}-90$ at BNFP is estimated to cost 125 million 1983 dollars. The $\$ 25$ million increase over the Sr facilities is principally for additional encapsulation capability. The operating costs should also increase $25 \%$ to about $\$ 25 \mathrm{million} /$ year. $\mathrm{Pm}-147$ and $\mathrm{Sr}-90$ recovery facilities at BNFP would have the same FY1988 startup date as the Sr-90 only

facilities.

\section{Unit Recovery Costs}

\section{Strontium-90}

The unit recovery costs for $\mathrm{Sr}-90$ range from $\$ 0.88 / \mathrm{Ci}$ to $\$ 2.73 / \mathrm{Ci}$. Table 3 shows that BNFP is potentially the most economical source producing $45 \mathrm{MCi} /$ year at $\$ 0.88 / \mathrm{Ci}$ when processing 5-year old LWR fue 1. The BNFP recovery cost increases to $\$ 1.59 / \mathrm{Ci}$ if 20 -year fuel is processed. Approximately $7.2 \mathrm{MCi} /$ year of $\mathrm{Sr}-90$ can be recovered from SRP fresh acid waste at a cost of $\$ 1.15 / \mathrm{Ci}$. The most expensive source of $\mathrm{Sr}-90$ is recovery from DWPF costing $\$ 2.73 / \mathrm{Ci}$ for $9 \mathrm{MCi} /$ year. 
Hanford Sr-90 recovery costs are not available. Recovery of Sr-90 from existing wastes is expected to be less than SRP recovery costs because facilities for separation and encapsulation of the radionuclides are currently operational. Recovery costs from fisture Purex acid wastes are expected to be comparable to those shown for SRP acid waste recovery.

The above unit costs are calculated from a discounted cash flow analysis to ensure recovery of projected expenditures. 22 The analysis assumes a 15-year study period from FY1983 through 1997 which includes a 10-year production campaign from FY1988 through FY1997. A $10 \%$ discount rate is employed which approximates the cost of government debt over the projected time. 23 Details of the discount analysis methods, along with cash flow tables for the various recovery options, are shown in the Appendix.

\section{$\underline{\text { Prome thium-147 }}$}

The Pm-147 unit recovery costs are shown in Table 4. The Pm-147 costs are expressed both as incremental and as allocated unit costs. The incremental unit cost values consider only the $\mathrm{Pm}$ capital and operating costs that are incremental to the Sr-90 costs. The allocated unit recovery costs are based on assigning $50 \%$ of the capital and operating costs to each isotope. The allocation method is probably more reasonable for determining the $\mathrm{Pm}-147$ recovery cost since most of the facilities required for $\mathrm{Pm}$ recovery are also required for $\mathrm{Sr}$ recovery. The allocation method increases the $\mathrm{Pm}-147$ cost to a more equitable leve 1 and reduces the $\mathrm{Sr}-90$ cost to reflect the economic advantages of recovering two isotopes.

Table 4 shows that SRP provides the most economical source of Pm-147. SRP can supply $36.0 \mathrm{MCi} /$ year at an incremental cost of $\$ \$ 0.07 / \mathrm{Ci}$. On an allocated basis, $\mathrm{Pm}-147$ recovered with $\mathrm{Sr}-90$ from SRP fresh waste costs $\$ 0.15 / \mathrm{Ci}$ which reduces the $\mathrm{Sr}-90$ cost from $\$ 1.15 / \mathrm{Ci}$ to $\$ 0.74 / \mathrm{Ci}$. The incremental recovery cost of Pm-i47 at $\mathrm{BNFP}$ is $\$ 0.69 / \mathrm{Ci}$. Cost allocation increases the $\mathrm{Pm}-147$ cost to $\$ 1.72 / \mathrm{Ci}$ and reduces the $\mathrm{Sr}-90$ cost from $\$ 0.88 / \mathrm{Ci}$ to $\$ 0.55 / \mathrm{Ci}$. The BNFP recovery cost is strongly influenced by the short 2.6 year half-life of $\mathrm{Pm}-147$. With 5-year old LWR spent fuel the Pm-147 content is only $25 \%$ (two half-lives) of the original discharged value. The facility capital and operating cost requirements are dependent on the metric tons of fuel processed rather than the number of curies of $\mathrm{Pm}-147$ recovered. The older age of the LWR spent fuel versus the age of SRP fuel at the time of processing results in the higher $\mathrm{Pm}-147$ unit recovery costs at BNFP. 
Heat Source Requirements versus Availability

The projected supply of high isotopic purity (>40\%) $\mathrm{Sr}-90$ for use in DOD heat source designs cannot be met by FY1990 without reprocessing commercial spent fuels. SRP fresh acid wastes can only supply about $22 \mathrm{MCi}$ between FY1988 and FY1990. Hanford can supply an additional $46 \mathrm{MCi}$ by FY1990 from the current inventory of capsules and the future processing of $\mathrm{N}$-reactor fuels. The other quantities of the $\mathrm{Sr}-90$ in existing waste inventories at Savannah River and Hanford are unsuitable for use in these heat source designs because of their low isotopic purity. The only additional supply of $\mathrm{Sr}-90$ is from reprocessing LWR spent fuel at BNFP. BNFP would have the capability of recovering up to $135 \mathrm{MCi}$ of $\mathrm{Sr}-90$ by FY1990 if 5-year old LWR spent fuel is reprocessed.

The DOD demand of $150 \mathrm{MCi}$ of $>40 \% \mathrm{Sr}-90$ by FY1990 may not be met even with commercial fuel reprocessing. BNFP, if started, would most likely reprocess older fuel. The amount of $\mathrm{Sr}-90$ available from BNFP by FY 1990 could be as low as $75 \mathrm{MCi}$ if 20-year old LWR spent fuel is reprocessed. This, together with $22 \mathrm{MCi}$ from SRP and $46 \mathrm{MCi}$ from Hanford, would fall short of the $150 \mathrm{MCi}$ demand. The recovery of $\mathrm{Pm}-147$ would increase the total heat source supply, but it would not impact the basic Sr-90 demand.

Some enhancement of the Sr-90 supply at isotopic purity levels of $>40$ could be obtained by blending low isotopic purity with high isotopic purity stock. In a typical case, the high purity product from SRP and Hanford fresh acid waste processing (assumed 55\% $\$ r-90)$ could be blended with previously separated Hanford inventory (assumed $35 \% \mathrm{Sr}-90$ ) to yield an additional $40 \mathrm{MCi}$ of $40 \%$ product by FY 1990 .

SRP and Hanford can meet the projected DOD requirements of $150 \mathrm{MCi}$ of Sr-90 by FY1990 without reprocessing LWR spent fuel by lowering the isotopic specification to $>30 \% \mathrm{Sr}-90$. By blending the low isotopic purity $\mathrm{Sr}$ from the HLW inventories with the high isotopic purity $\mathrm{Sr}$ recovered from fresh acid wastes, SRP and Hanford could supply $149 \mathrm{MCi}$ by FY1990. Blending increases the SRP output to 49 $\mathrm{MC} i$ and the Hanford output to $100 \mathrm{MCi}$.

JEH/WRM : pph 
P. L. Roggenkamp

\section{References}

1. Carpenter, R T., "Status of U.S. Radioisotopic Space Power Systems", Isotopes and Radiation Technology, 9(No. 3), 1972.

2. Secken, S. J. and W. A. Bair. "Terrestrial Isotope Power Systems in Perspective", Materials for Radio-Isotope Heat Sources, Eds. D. E. Thomas, W. O. Harms, and R. T. Huntoon, Nuclear Metallurgy, Vo1. 14, 1968.

3. Drumheller, K. "Properties and Fabrication of Promethium Fuel Forms", Materials for Radio-Isotope Heat Sources (Nuclear Metallurgy, Vo 1. 14).

4. Fullam, H. T. Design and Qualification Testing of a Strontium-90 Fluoride Heat Source, Pacific Northwest Laboratory, PNL-3923, Dec. 1981.

5. Spent Fuel and Radioactive Waste Inventories and Projections as of December 31, 1980, DOE/NE-0017, September, 1981.

6. Waste Management Programs, Report for December 1981, DPSP-81-21-12, Savannah River Plant, December, 1981.

7. Sheldon, E. B., Sr-90 and Pm-147 in Savannah River Plant Waste, DPSP-65-1273, April 19, 1965.

8. Waste Management Programs, Report for December 1980, DPSP-80-21-12, Savannah River Plant, December 1980.

9. Study of the Separation and Recovery of Selected Radioisotopes from Commercial Nuclear Spent Fuel Wastes, XN-FR-ER-2, Rev. 1, January, 1978.

10. Beard, S. J., Smith, P. W., and Cochran, J. S., Processing and Source Preparation of Separated Fission Products, Large Scale Production and Applications of Radioisotopes, DP-1066, Volume I, May 1966.

11. Randa11, C. T., Technical Description, Acid Waste Vitrification, DPST-80-404, April 8, 1982.

12. Technical Aspects of Long-Term Management Alternatives for High-Level Defense Waste at the Hanford Site, RHO-LD-141, October 1980. 
13. Letter, J. C. Eargle to T. B. Hindman, DOE-SR, May 6, 1982.

14. Kelsch, R. D., A. J. Lethco, and J. B. Mellen, "Multi-purpose Processing Facility to Separate Actinides", Proc. 20th Conf. on Remote Systems Technology, 1972, p. 235.

15. Jackson, R. R., "Hanford Waste Encapsulation: Strontium and Cesium", Nucl. Tech. 32, 10 (1977).

16. Evaluation of Utilization of Barnwell Nuclear Fuel Plant in Support of the U.S. Breeder Reactor Reprocessing Program, ORNL/TM-7719, March, 1981.

17. Savannah River Plant Nuclear Material Production Facilities Restoration Study, Third Annual Reappraisal, May 1982.

18. Allender, J. S., DPST-82-606, Cost Estimates for Alternative $\mathrm{P} / \mathrm{M}$ Facility Designs, June 1, 1982 .

19. Cost Report, Section I, Combined Cost Statement \& Production Costs, DPSP-81-11-9, September, 1981.

20. Defense Waste Processing Facility, Alternative Waste Forms Response to Processability Analysis and Venture Guidance Appraisal Questions, DL0000040, January 13, 1982.

21. Final Environmental Impact Statement, Defense Waste Processing Facility, Savannah River Plant, Aiken, S.C., DOE/EIS-0082, February 1982.

22. Preliminary Estimates of the Charge for Spent-Fuel Storage and Disposal Services, DOE/ET-0055, July 1978.

23. Forster, J. D. and S. Cohen., The Discount Rate in the Spent Fuel Storage and Disposal Fee, ONWI-189, April 1980. 
Table 1. Sr-90 Feed Sources

Existing Inventory Quantity Isotopic (MCi)

SRP

Hanford

- HLW

- SrF 2 Capsules

- N-Reactor

LWR Spent Fuel

120 Purity $(\% \text { sr-90 })^{a}$

$20-50$

Annua 1 Production (MCi/yr)

$10.0^{b}$

a. Percent $5 r-90$ to total $\mathrm{Sr}$ present.

b. Four SRP reactors operating at full power. $6,7,8$

c. Contains $10 \mathrm{MCi}$ with an $\mathrm{Sr}-90$ isotopic purity of $>40 \%$.

d. Consists of 2800 MT of unprocessed $N$-reactor fuel irradiated since 1972.

e. Percent $\mathrm{Sr}-90$ as formed. No radioactive decay of Sr-90 included. 
Table 2. Pm-147 Feed Sources

\begin{tabular}{|c|c|}
\hline $\begin{array}{l}\text { Existing } \\
\text { Inventory } \\
\text { (MCi) }\end{array}$ & $\begin{array}{l}\text { Annual } \\
\text { Production } \\
\text { (MCi/yr) }\end{array}$ \\
\hline $85^{a}$ & $50^{b}$ \\
\hline $14^{c}, d$ & 12 \\
\hline $400^{c}$ & 135 \\
\hline
\end{tabular}

a. Inventory as of 1982 per Reference 6 .

b. Four SRP reactors operating. $6,7,8$

c. Inventory as of 1982 per Reference 5 .

d. Does not include 2800 MT of unprocessed $N$-reactor fue 1 irradiated since 1972 . 
Table 3. Strontium-90 Unit Recovery Costs

\begin{tabular}{ll}
$\begin{array}{l}\text { Annual Amount } \\
\text { (MCi/yr) }\end{array}$ & $\begin{array}{l}\text { Capital Requireda Annual Operatinga Unit Costa,b } \\
\left(\$ 10^{6}\right)\end{array}$ \\
\hline
\end{tabular}

SRP

- DWPF Recoveryc

7.2

9.0

2.3

Hanford

- Fresh Purex Wasted

- Existing Inventory

BNFP

- 5 yr old fue $1^{c}$

- 20 yr old fue $1^{c}$

100

30

100

3

1.15

2.73

$-$

a. Values are 1983 dollars.

b. Unit cost based on a discounted cash flow analysis with a $10 \%$ discount rate. (See Appendix.)

c. The amount recovered is $72 \%$ of the $\mathrm{Sr}$ present in the waste.

d. The amount recovered is $90 \%$ of the $\mathrm{Sr}$ present in the waste. 
Table 4. Strontium-90 and Promethium-147 Unit Recovery Costs

\begin{tabular}{|c|c|c|c|c|c|c|}
\hline $\begin{array}{l}\text { Annu } \\
\text { (MCi }\end{array}$ & & $\begin{array}{l}\text { Capital } \\
\text { Requi reda }\end{array}$ & $\begin{array}{l}\text { Annual } \\
\text { Operating }\end{array}$ & $\begin{array}{l}\text { Incr } \\
\text { Cost }\end{array}$ & $\begin{array}{l}1 \text { Unit } \\
a, b\end{array}$ & $\begin{array}{l}\text { Allocated Unit } \\
\text { Cost }(\$ / C i) a, b, c\end{array}$ \\
\hline$S r-90$ & $P m-147$ & & Costs $\left(\$ 10^{6} / \mathrm{yr}\right)$ & $\overline{\mathrm{Sr}-90}$ & $\mathrm{Pm}-147$ & $P m-147$ \\
\hline
\end{tabular}

\section{SRP Fresh}

Acid Waste ${ }^{d}$

Hanford Purex

Acid Waste $\mathrm{e}, \mathrm{f}$

BNFP Reprocessing

5 Yr Old Fue $1^{d}$
35

45

$2.3 \quad 11.0$

$7.2 \quad 36.0$

20
4.5

$-$

25
$\mathrm{Sr}-90 \quad \mathrm{Pm}-147$

a. Values are 1983 dollars.

b. Unit cost based on a discounted cash flow analysis with a $10 \%$ discount rate. (See Appendix.)

c. Unit cost based on $50 \%$ of the capital and operating costs allocated to each isotope.

d. The amount recovered is $72 \%$ of the $\mathrm{Sr}$ and $\mathrm{Pm}$ present in the waste.

e. The amount recovered is $90 \%$ of the $\mathrm{Sr}$ and $\mathrm{Pm}$ present in the waste.

f. Current annual N-reactor production only. Does not include 2800 MTU of unprocessed $\mathrm{N}$-reactor fuel irradiated since 1972. 
Figure 1. ${ }^{90} \mathrm{Sr}$ Heat Source Capsules

$\frac{\text { Inner Capsule }}{\text { Haste11oy } \mathrm{C}-276}$

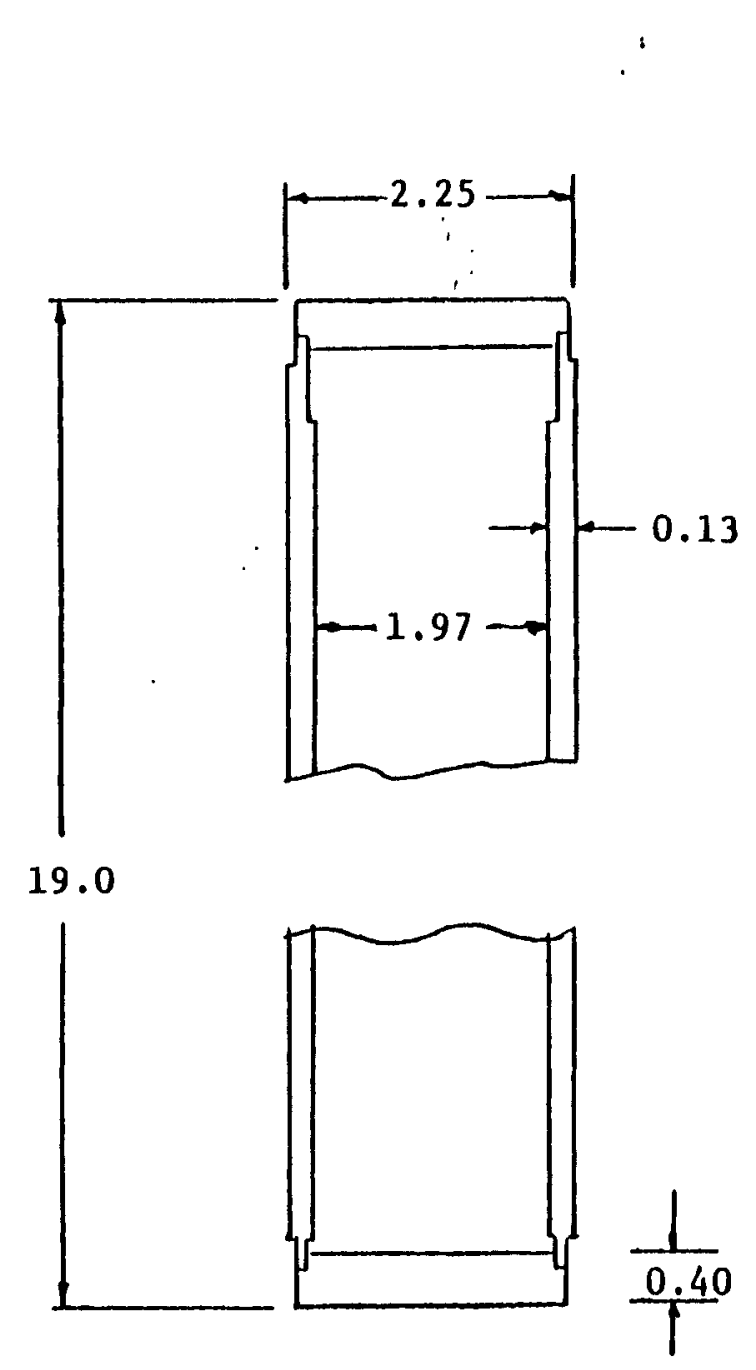

\section{Outer Capsule}

Hastelloy $\mathrm{C}-4$ or $\mathrm{S}$
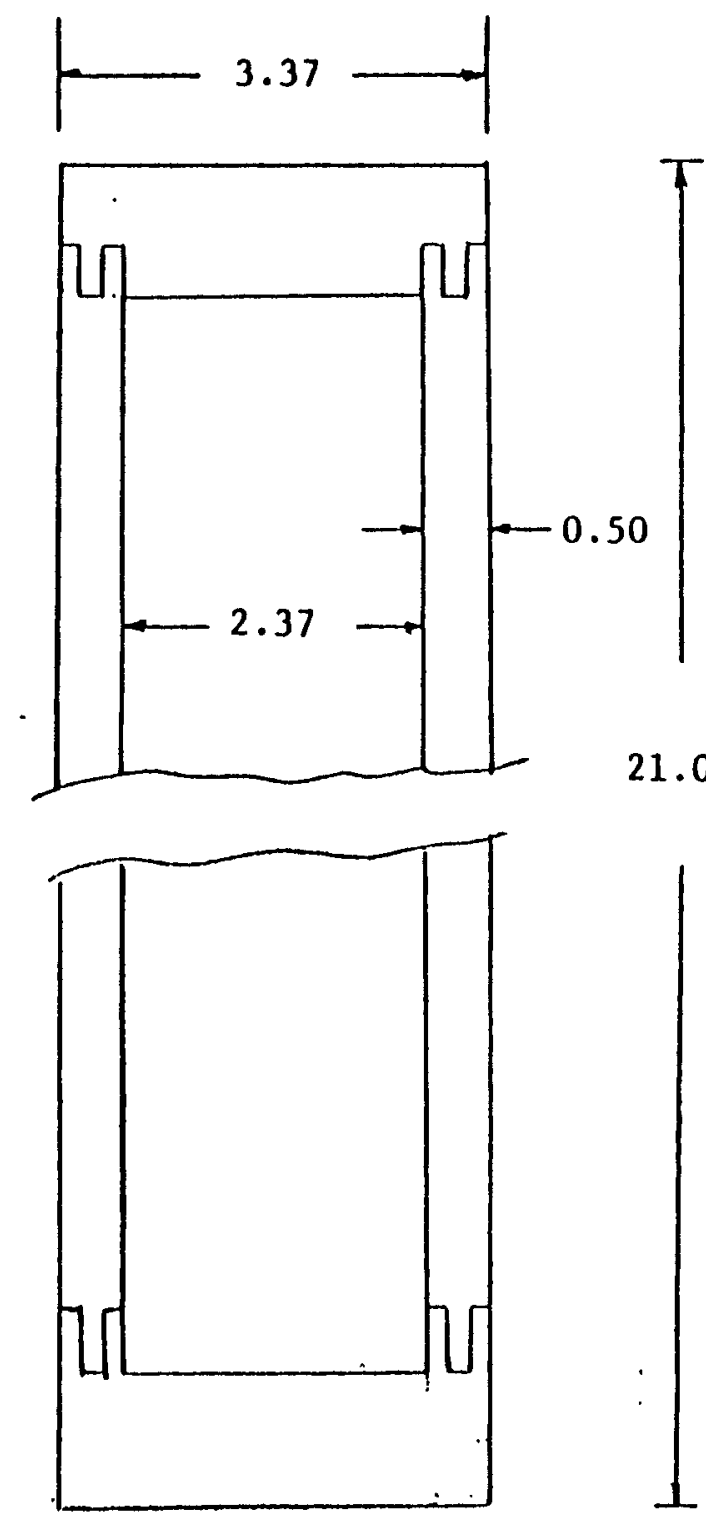

?

5

梁

$\underset{\infty}{\infty}$

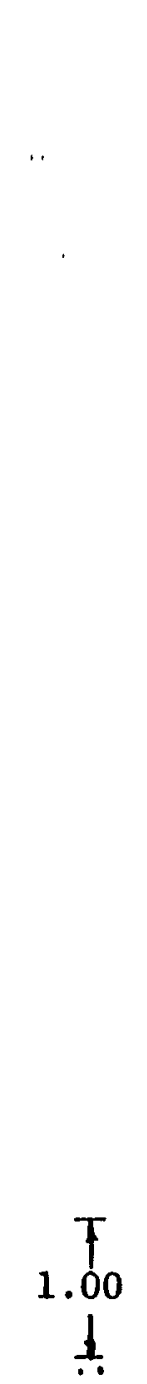

Inches 
F1gure 2. ${ }^{90}$ Sr Recovery from Acid SRP Waste

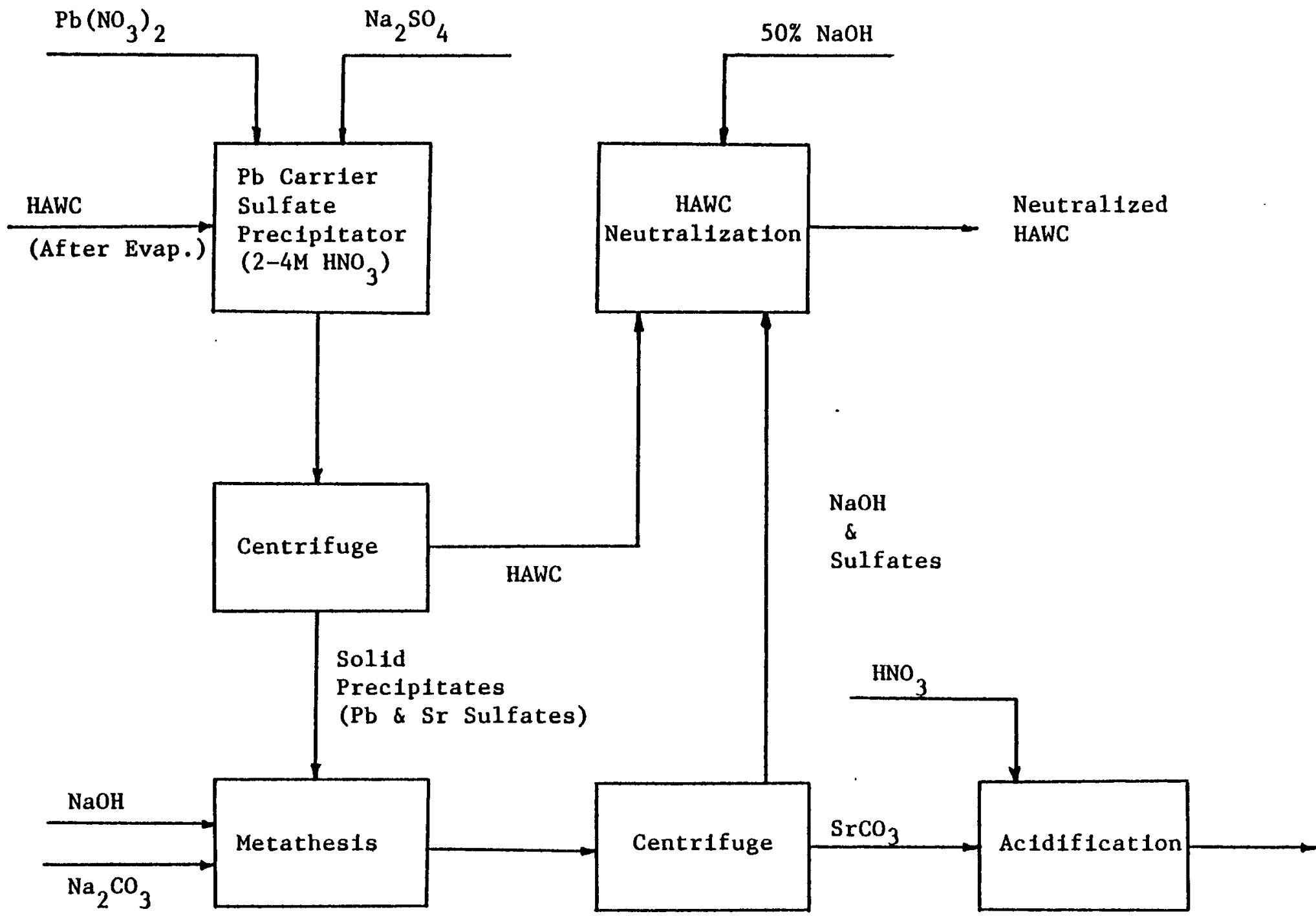

$\mathrm{Sr}\left(\mathrm{NO}_{3}\right)_{2}^{\mathrm{a}}$

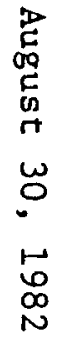


Figure 3. ${ }^{90}$ Sr Recovery from DWPF

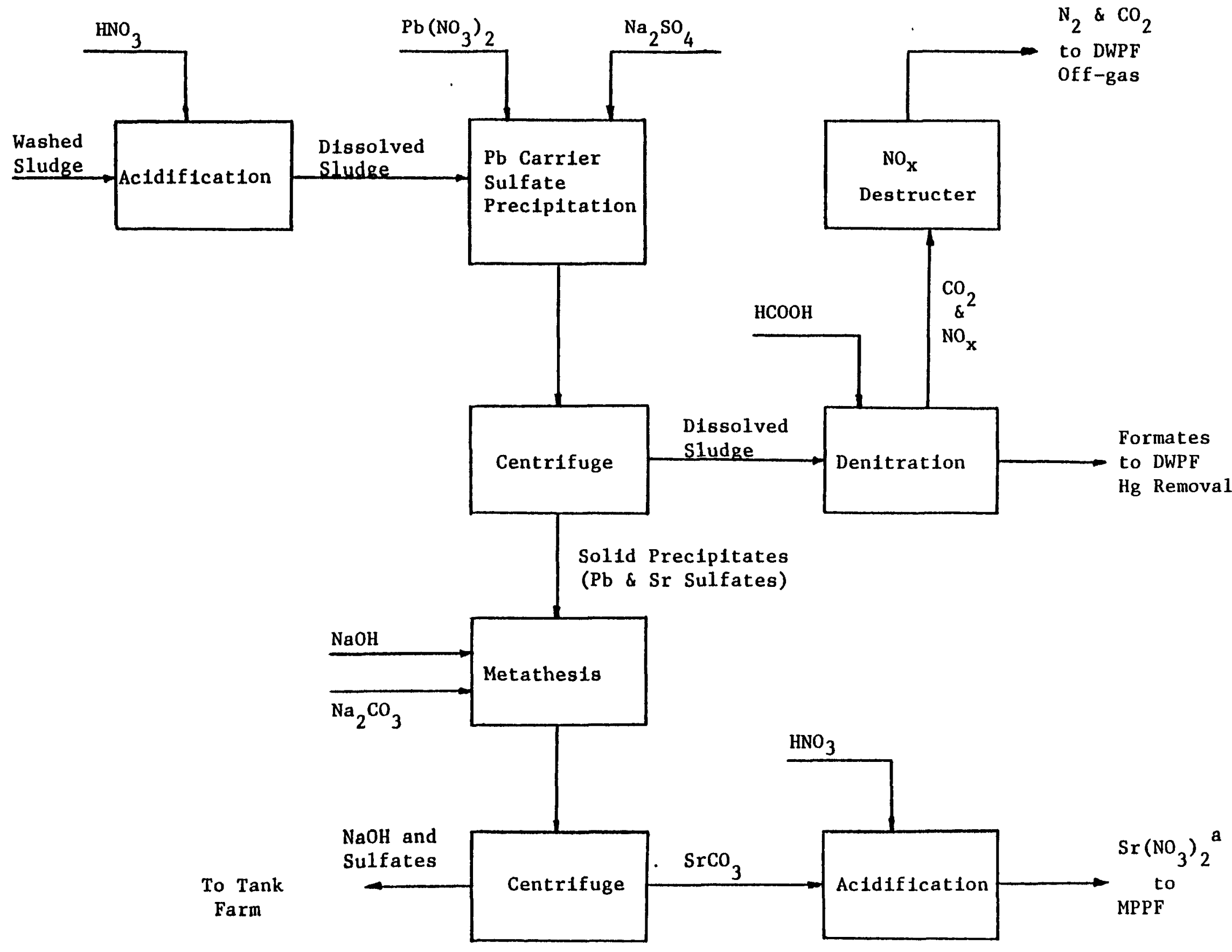


Figure 4. $\quad{ }^{90} \mathrm{Sr}$ and ${ }^{147} \mathrm{Pm}$ Recovery from Actd SRP Waste
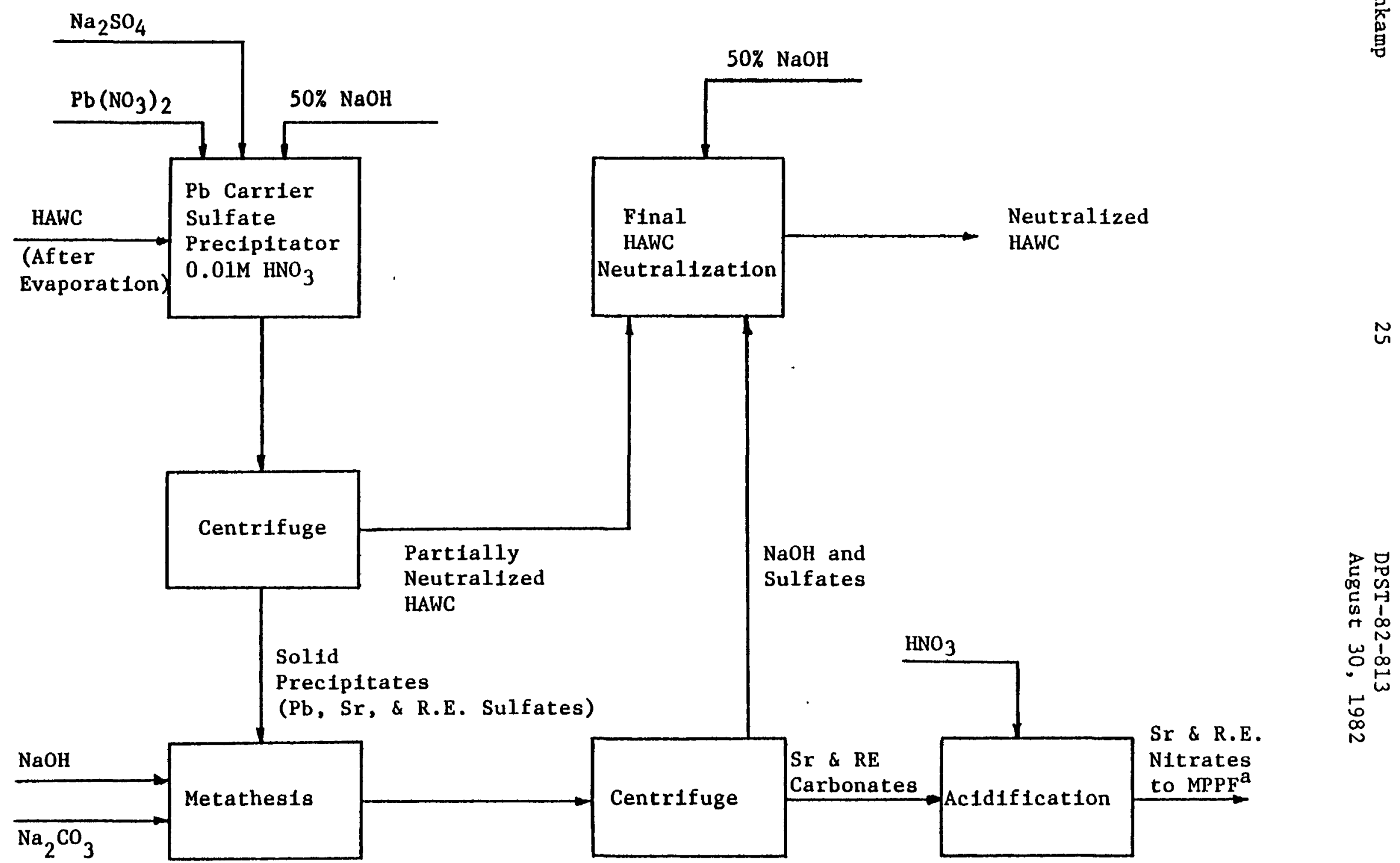

a. $80 \%$ of Sr and $\mathrm{Pm}$ In HAWC is recovered. 
Figure 5. ${ }^{90} \mathrm{Sr}$ and ${ }^{147} \mathrm{Pm}$ Encapsulation

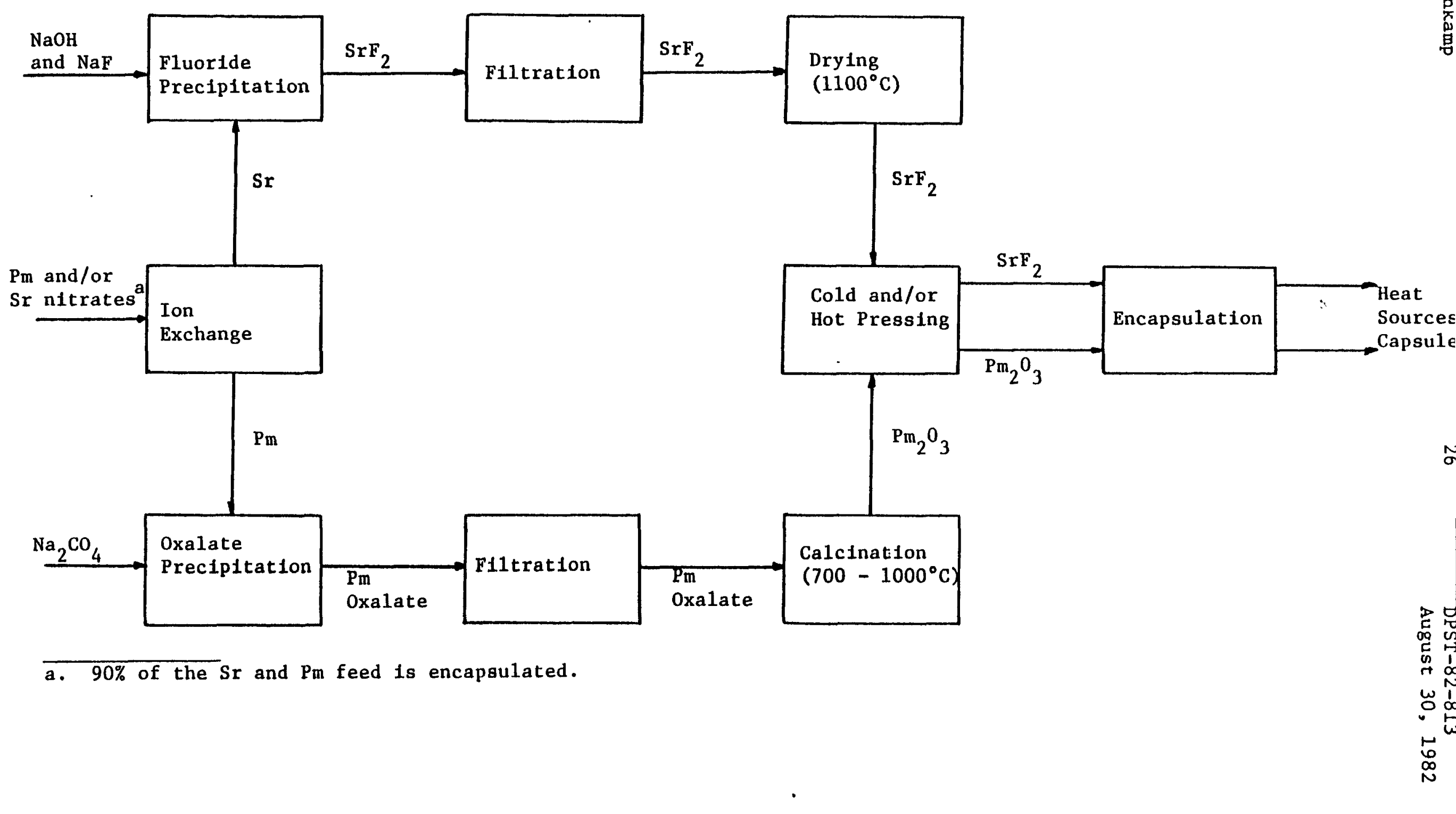


Figure 6. Multi-Purpose Processing Facility

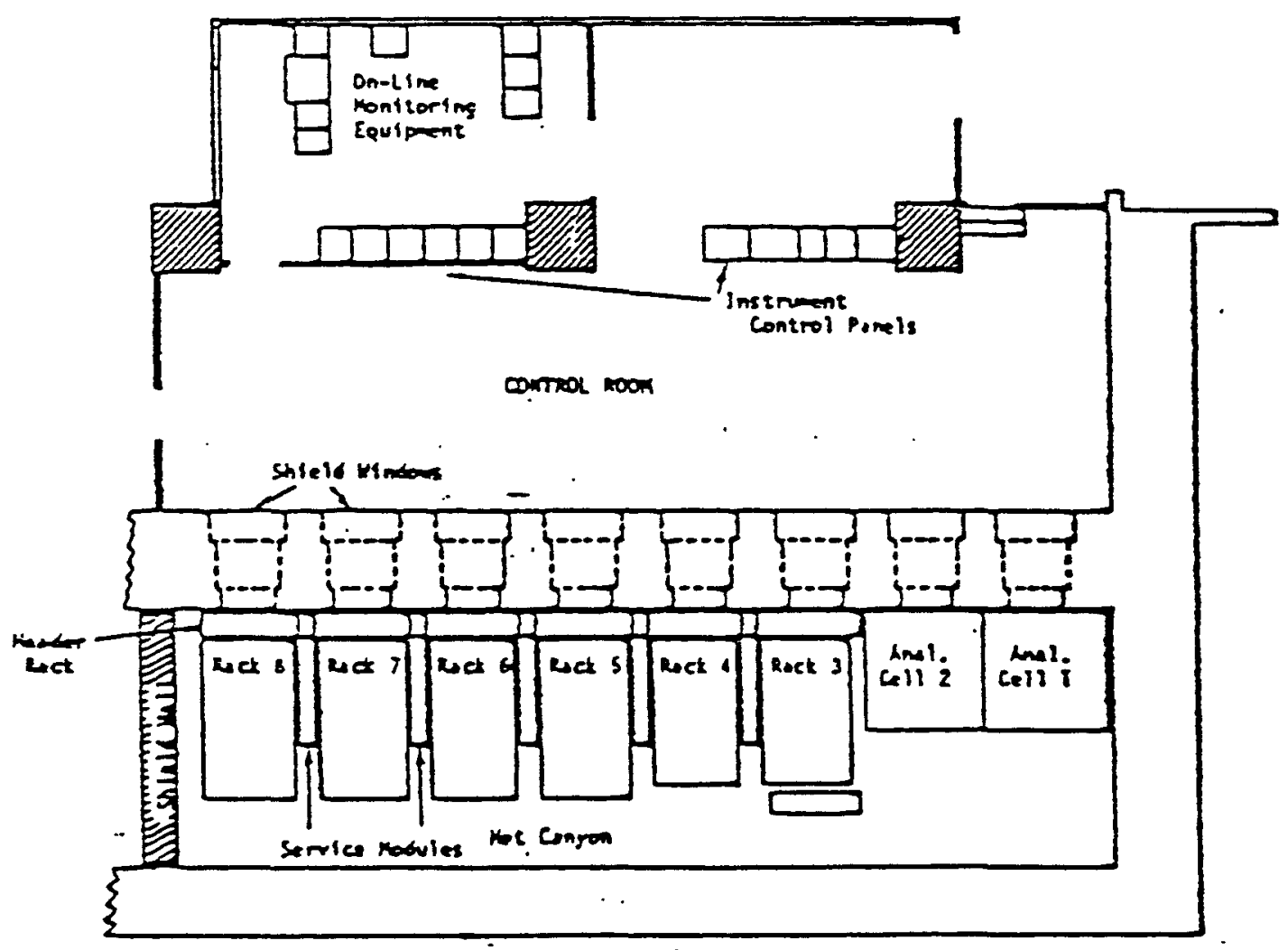

a. The MPPF is located in the north end of the F-Area Hot Canyon. 


\section{APPENDIX - UNIT COST ANALYSIS}

The unit costs for strontium-90 and promethium-147 recovery are calculated using standard discounting procedures for pricing Government services. Such procedures are based on full recovery of Government costs over a reasonable time period. The prices for services (or products) are established such that the present value of revenues received equal the present value of costs incurred over the selected time period. 22 The discounted revenue can be expressed as the price (or unit cost) multiplied by the discounted number of unit (curies of product) provided. Therefore, the unit costs can be determined by

$$
\text { Unit cost }=\frac{\text { Discounted Government Cost }}{\text { Discounted Curies of Product }}
$$

The present analysis utilizes a 15-year study period from FY1983 through FY1997. Capital expenditures are incurred during the five year period of FY1983 through FY1987. Operating costs are incurred during the ten year period of FY1988 through FY1997. No research and development charges are included. The discounted Government costs are calculated as net present values of expenditures in constant 1983 dollars. The discounted curies of product are calculated by multiplying the number of curies recovered in a given year by the discount factor appropriate for that year. The discount rate ( $10 \%$ ) was selected to approximate recent costs (interest charges) of Government debt. Use of such a discount rate, which includes a portion of interest attributable to receipt of inflated dollars, assumes and requires an annual recalculation of the unit cost of product be made to ensure the recovery of all Government costs including inflation. 23

Cash flows and unit costs for the various product recovery scenarios considered in this report are shown in Tables $A-1$ through A-8. 
Table A-1. Strontium-90 Recovery Cost from Fresh SRP Waste

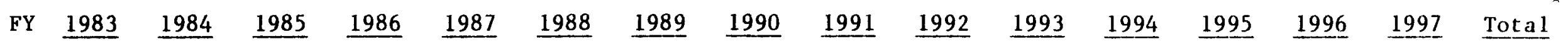

$\underline{\text { Recovery Costs }}{ }^{a}$

\begin{tabular}{|c|c|c|c|c|c|c|c|c|c|c|c|c|c|c|c|c|}
\hline Capital & 0 & 0 & 5 & 15 & 10 & - & - & - & - & - & - & - & - & - & - & 30 \\
\hline Operating & - & - & - & $=$ & - & 3 & 3 & 3 & 3 & 3 & 3 & 3 & 3 & 3 & 3 & 30 \\
\hline Total Cost & 0 & 0 & 5 & 15 & 10 & 3 & 3 & 3 & 3 & 3 & 3 & 3 & 3 & 3 & 3 & 60 \\
\hline
\end{tabular}

Curies Recovered

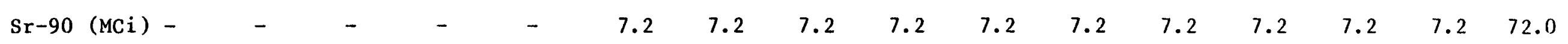

\section{Net Present Values}

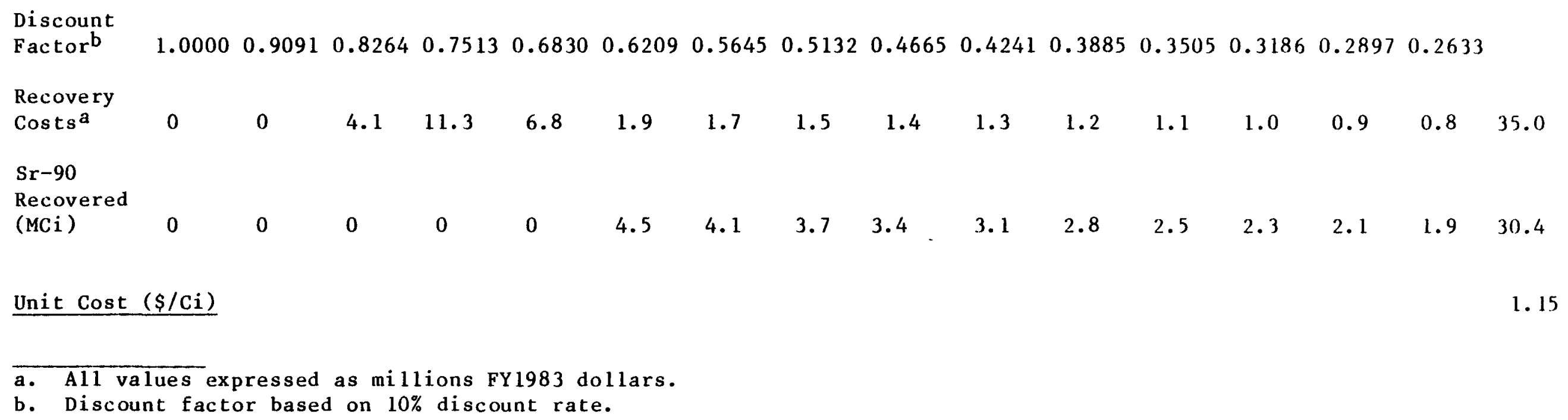


Table A-2. Strontium-90 Recovery Cost from DWPF

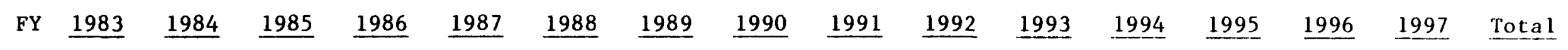

\section{$\underline{R e c o v e r y}$ Costs $^{a}$}

\begin{tabular}{|c|c|c|c|c|c|c|c|c|c|c|c|c|c|c|c|c|}
\hline Capita 1 & 10 & 25 & 25 & 25 & 15 & - & - & - & - & - & - & - & - & - & - & 100 \\
\hline Operating & - & - & - & - & - & 5 & 5 & 5 & 5 & 5 & 5 & 5 & 5 & 5 & 5 & 50 \\
\hline Total Cost & 10 & 25 & 25 & 25 & 15 & 5 & 5 & 5 & 5 & 5 & 5 & 5 & 5 & 5 & 5 & 150 \\
\hline Curies Rec & ove & & & & & & & & & & & & & & & \\
\hline $\mathrm{Sr}-90 \quad(\mathrm{MCi}$ & - & - & - & - & - & 9.0 & 9.0 & 9.0 & 9.0 & 9.0 & 9.0 & 9.0 & 9.0 & 9.0 & 9.0 & 90.0 \\
\hline
\end{tabular}

\section{Net Present Values}

Discount

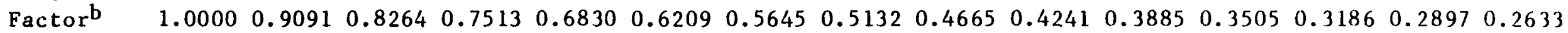

\begin{tabular}{|c|c|c|c|c|c|c|c|c|c|c|c|c|c|c|c|c|}
\hline $\begin{array}{l}\text { Recovery } \\
\text { Costs }\end{array}$ & 10.0 & 22.7 & 20.7 & 18.8 & 10.2 & 3.1 & 2.8 & 2.6 & 2.3 & 2.1 & 1.9 & 1.8 & 1.6 & 1.4 & 1.3 & 103.3 \\
\hline $\mathrm{Sr}-90$ & & & & & & & & & & & & & & & & \\
\hline $\begin{array}{l}\text { Recovered } \\
\text { (MCi) }\end{array}$ & 0 & 0 & 0 & 0 & 0 & 5.6 & 5.1 & 4.6 & 4.2 & 3.8 & 3.5 & 3.2 & 2.9 & 2.6 & 2.4 & 37.9 \\
\hline
\end{tabular}

Unit Cost $(\$ / \mathrm{Ci})$ 
Table A-3. BNFP Strontium-90 Recovery Cost from 5-Year 01d LWR Fue ${ }^{\mathrm{a}}$

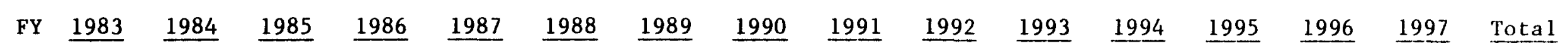

$\underline{\text { Recovery } \operatorname{Costs}}{ }^{b}$

\begin{tabular}{|c|c|c|c|c|c|c|c|c|c|c|c|c|c|c|c|c|}
\hline Capita 1 & 10 & 25 & 25 & 25 & 15 & - & - & - & - & - & - & - & - & - & - & 100 \\
\hline Operating & - & - & - & - & - & 20 & 20 & 20 & 20 & 20 & 20. & 20 & 20 & 20 & 20 & 200 \\
\hline $\begin{array}{l}\text { Total Cost } \\
\text { Curies Rec }\end{array}$ & 10 & 25 & 25 & 25 & 15 & 20 & 20 & 20 & 20 & 20 & 20 & 20 & 20 & 20 & 20 & 300 \\
\hline $\mathrm{Sr}-90 \quad(\mathrm{MC}$ & - & - & - & - & - & 45 & 45 & 45 & 45 & 45 & 45 & 45 & 45 & 45 & 45 & 450 \\
\hline
\end{tabular}

\section{Net Present Values}

Discount

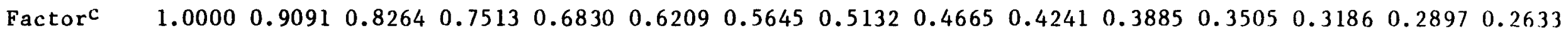

Recovery

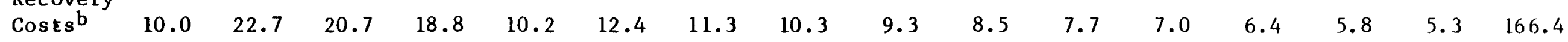

Sr-90

Recovered

(MCi)

$\begin{array}{lllll}0 & 0 & 0 & 0 & 0\end{array}$

$27.9 \quad 25.4 \quad 23.1$

21.0

$\begin{array}{lll}19.1 & 17.3 & 15.8\end{array}$

14.3

13.

11.

188.7

Unit Cost $(\$ / \mathrm{Ci})$

a. LWR fuel ir radiated 33,000 MWD/MT.

b. All values expressed as millions FY1983 dollars.

c. Discount factor based on $10 \%$ discount rate. 
Table A-4. BNFP Strontium-90 Recovery Cost from $: 20$-Year 01d LWR Fue ${ }^{a}$

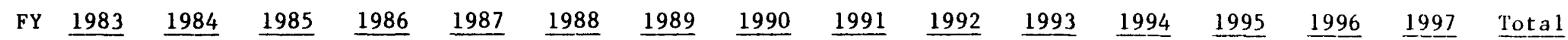

\section{$\underline{\text { Recovery Costs }}$}

\begin{tabular}{|c|c|c|c|c|c|c|c|c|c|c|c|c|c|c|c|c|}
\hline Capital & 10 & 25 & 25 & 25 & 15 & - & - & - & - & - & - & - & - & - & - & 100 \\
\hline Operating & - & - & - & - & - & 20 & 20 & 20 & 20 & 20 & 20 & 20 & 20 & 20 & 20 & 200 \\
\hline Total Cost & 10 & 25 & 25 & 25 & 15 & 20 & 20 & 20 & 20 & 20 & 20 & 20 & 20 & 20 & 20 & 300 \\
\hline \multicolumn{17}{|c|}{ Curies Recovered } \\
\hline $\mathrm{Sr}-90(\mathrm{MC} \mathrm{I})$ & - & - & - & - & - & 25 & 25 & 25 & 25 & 25 & 25 & 25 & 25 & 25 & 25 & 250 \\
\hline
\end{tabular}

\section{Net Present Values}

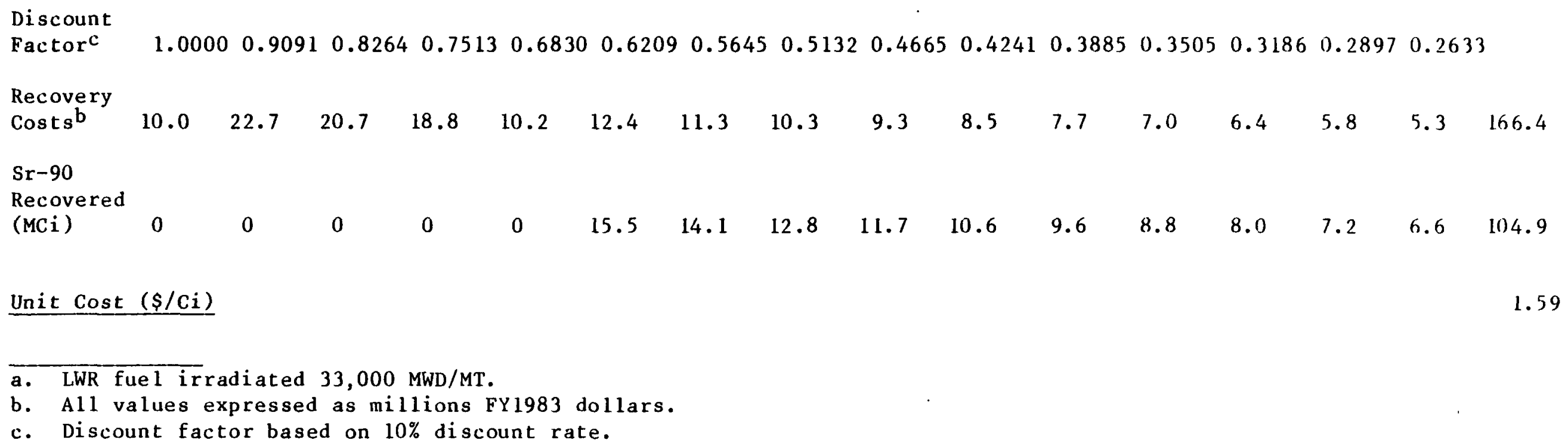

a. LWR fuel ir radiated 33,000 MWD/MT.

b. All values expressed as millions FY1983 dollars.

c. Discount factor based on $10 \%$ discount rate. 
Table A-5. Incremental Unit Cost of Promethium-147 Recovery from Fresh SRP Waste

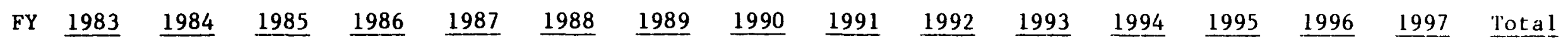

Recovery $\underline{\operatorname{Costs}}^{\mathrm{a}, \mathrm{b}}$

\begin{tabular}{|c|c|c|c|c|c|c|c|c|c|c|c|c|c|c|c|c|}
\hline $\begin{array}{l}\text { Capital } \\
\text { Operating }\end{array}$ & - & - & $\begin{array}{l}1 \\
-\end{array}$ & $\begin{array}{l}2 \\
- \\
\end{array}$ & $\begin{array}{l}2 \\
- \\
\end{array}$ & $\overline{1.5}$ & - & - & $\overline{1.5}$ & - & $\overline{1.5}$ & - & 1.5 & 1.5 & - & $\begin{array}{r}5 \\
15 \\
\end{array}$ \\
\hline Total Cost & 0 & 0 & 1 & 2 & 2 & 1.5 & 1.5 & 1.5 & 1.5 & 1.5 & 1.5 & 1.5 & 1.5 & 1.5 & 1.5 & 20 \\
\hline \multicolumn{17}{|c|}{ Curies Recovered } \\
\hline $\mathrm{Pm}-147(\mathrm{MCi})$ & - & - & - & - & - & 36.0 & 36.0 & 36.0 & 36.0 & 36.0 & 36.0 & 36.0 & 36.0 & 36.0 & 36.0 & 360 \\
\hline
\end{tabular}

\section{Net Present Values}

\begin{tabular}{|c|c|c|c|c|c|c|c|c|c|c|c|c|c|c|c|c|}
\hline $\begin{array}{l}\text { Discount } \\
\text { Factor }\end{array}$ & 1.0000 & 0.9091 & 0.8264 & 0.7513 & 0.6830 & 0.6209 & 0.5645 & 0.5132 & 0.4665 & 0.4241 & 0.3885 & 0.3505 & 0.3186 & 0.2897 & 0.2633 & \\
\hline $\begin{array}{l}\text { Recovery } \\
\text { Costs } a, b\end{array}$ & 0 & 0 & 0.8 & 1.5 & 1.4 & 0.9 & 0.8 & 0.8 & 0.7 & 0.6 & 0.6 & 0.5 & 0.5 & 0.4 & 0.4 & 9.9 \\
\hline $\begin{array}{l}\text { Pm- } 147 \\
\text { Recovered } \\
\text { (MCi) }\end{array}$ & 0 & 0 & 0 & 0 & 0 & 22.4 & 20.3 & 18.5 & 16.8 & 15.3 & 13.9 & 12.6 & 11.5 & 10.4 & 9.5 & 151.2 \\
\hline
\end{tabular}

a. All values expressed as millions FY1983 dollars.

b. Pm-147 recovery costs are incremental to $\mathrm{Sr}-90$ recovery costs shown in Table A-1.

c. Discount factor based on $10 \%$ discount rate. 
Table A-6. Strontium-90 and Promethium-147 Recovery Costs from Fresh SRP Waste

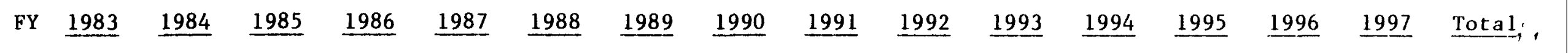

$\underline{\text { Recovery } \operatorname{Cost} s^{a}, b}$

\begin{tabular}{|c|c|c|c|c|c|c|c|c|c|c|c|c|c|c|c|c|}
\hline $\begin{array}{l}\text { Capital } \\
\text { operating }\end{array}$ & $\begin{array}{l}0 \\
- \\
\end{array}$ & $\begin{array}{l}0 \\
-\end{array}$ & $\begin{array}{l}6 \\
- \\
\end{array}$ & $\begin{array}{r}17 \\
- \\
\end{array}$ & $\begin{array}{r}12 \\
- \\
\end{array}$ & 4.5 & 4.5 & - & - & - & - & 4.5 & 4.5 & 4.5 & 4.5 & $\begin{array}{l}35 \\
45 \\
\end{array}$ \\
\hline Total Cost & 0 & 0 & 6 & 17 & 12 & 4.5 & 4.5 & 4.5 & 4.5 & 4.5 & 4.5 & 4.5 & 4.5 & 4.5 & 4.5 & 80 \\
\hline \multicolumn{17}{|c|}{ Curies Recovered } \\
\hline Sr-90 (MCi) & - & - & - & - & - & 7.2 & 7.2 & 7.2 & 7.2 & 7.2 & 7.2 & 7.2 & 7.2 & 7.2 & 7.2 & 72 \\
\hline Pm-147(MCi) & - & - & - & - & - & 36.0 & 36.0 & 36.0 & 36.0 & 36.0 & 36.0 & 36.0 & 36.0 & 36.0 & 36.0 & 360 \\
\hline
\end{tabular}

\section{Net Present Values}

Discount

$\begin{array}{llllllllllllllllll}\text { Factorc } & 1.0000 & 0.9091 & 0.8264 & 0.7513 & 0.6830 & 0.6209 & 0.5645 & 0.5132 & 0.4665 & 0.4241 & 0.3885 & 0.3505 & 0.3186 & 0.2897 & 0.2633\end{array}$

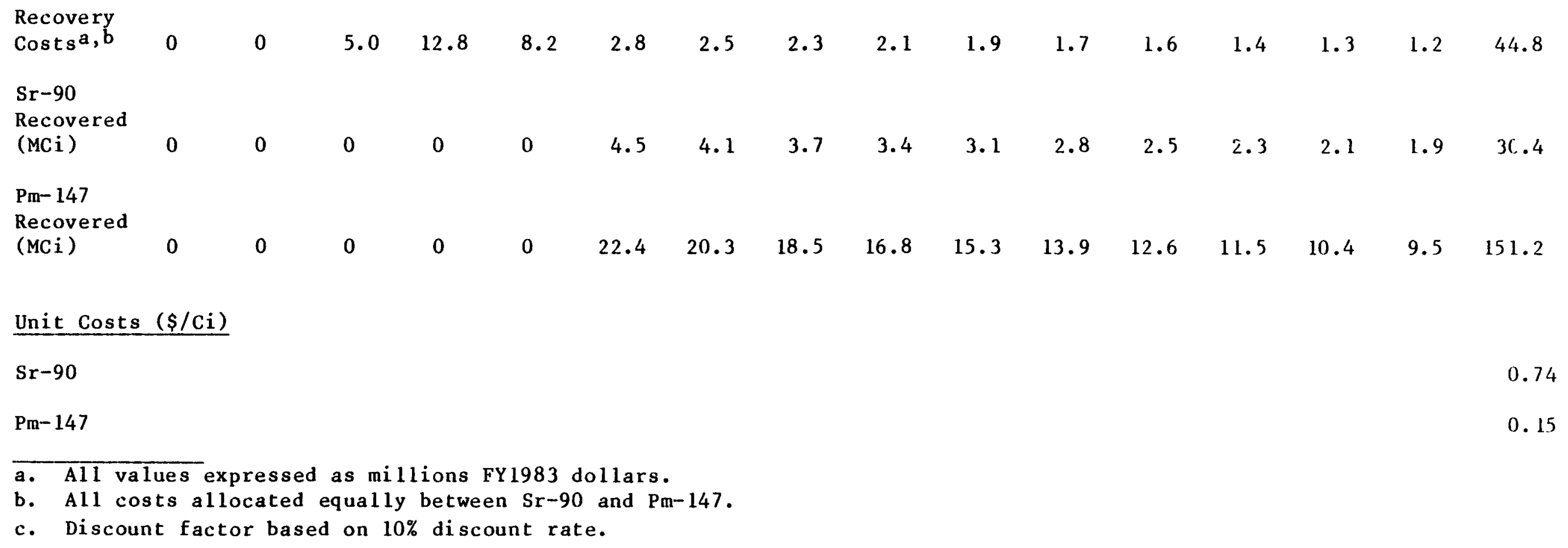


Table A-7. Incremental Unit Cost of Promethium-147 Recovery at BNFP

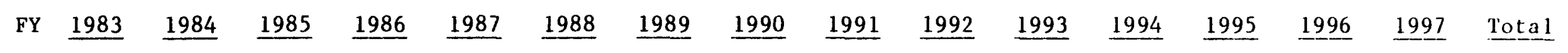

\section{$\underline{R e c o v e r y} \operatorname{Costs}^{a, b}$}

$\begin{array}{llllllllllllll}\text { Capital } & 3 & 6 & 6 & 6 & 4 & - & - & - & - & - & - & - & - \\ \text { Operating } & - & - & - & - & - & 5 & 5 & 5 & 5 & 5 & 5 & 5 \\ \text { Total Cost } 3 & 6 & 6 & 6 & 4 & 5 & 5 & 5 & 5 & 5 & 5 \\ 75\end{array}$

\section{Curies Recovered}

Pm-147(MCi) ${ }^{c}$

\section{Net Present Values}

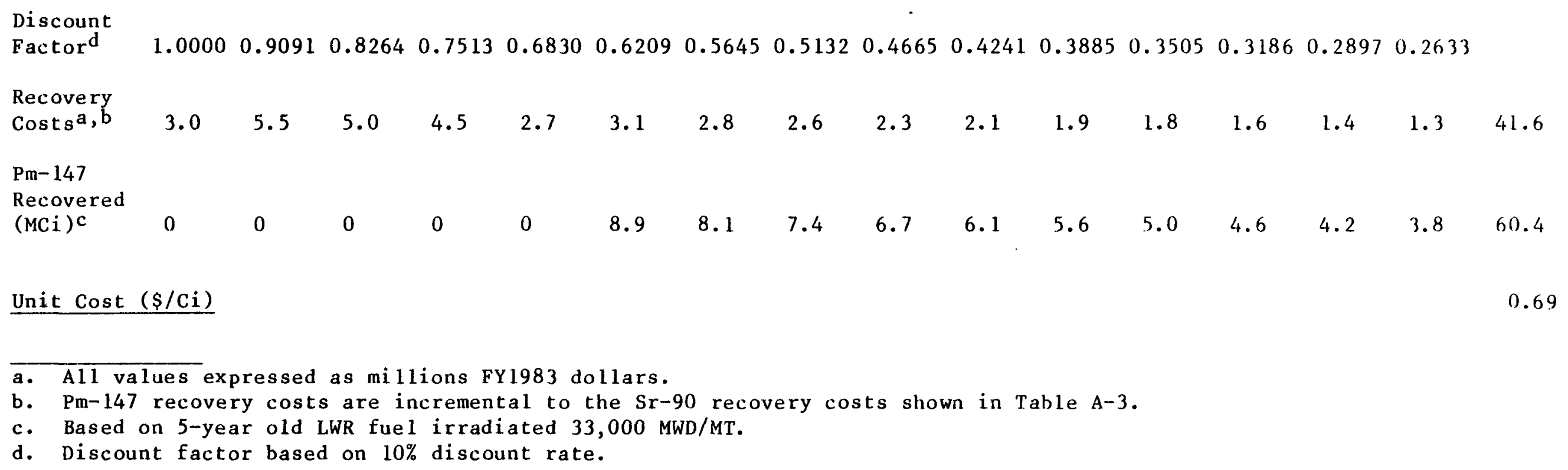

8.9

a. A11 values expressed as mi 11 ions FY1983 dollars.

b. Pm-147 recovery costs are incremental to the $\mathrm{Sr}-90$ recovery costs shown in Table A-3.

c. Based on 5-year old LWR fuel irradiated 33,000 MWD/MT.

d. Discount factor based on $10 \%$ discount rate. 
Table A-8. Strontium-90 and Promethium-147 Recovery Costs at BNFP

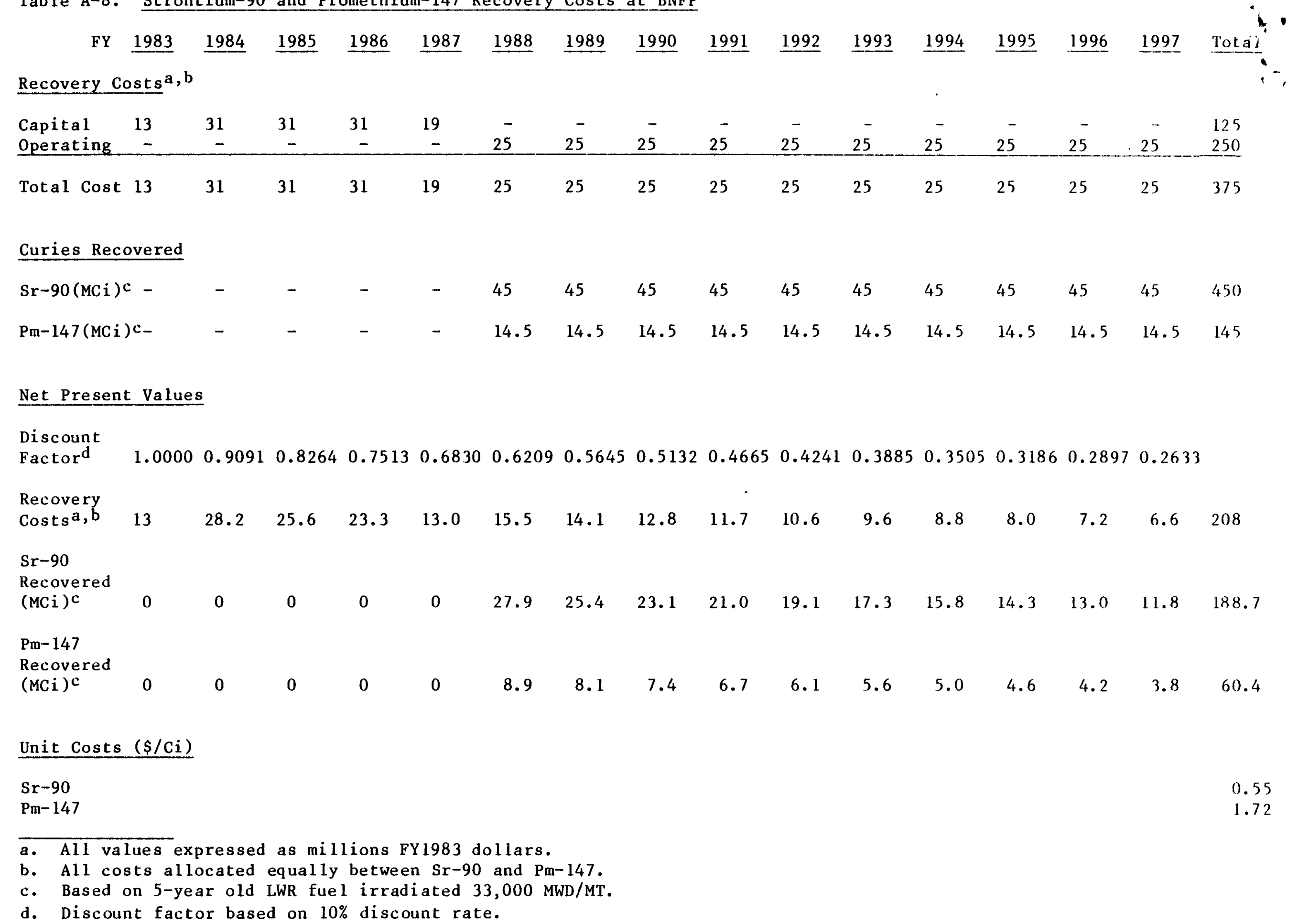

